\title{
Teacher Views of Teaching English through English (TETE) in Japanese Junior High Schools: Findings from the Inside
}

\section{Nathaniel David Reed}

\author{
ALT Training Online (altto.net)
}

\begin{abstract}
This study investigates teacher perspectives on a recent directive from the Japanese Ministry of Education (MEXT), which states that "lessons should be given in English at junior high schools (JHSs), in principle, according to the level of understanding of students" (MEXT, 2014, p. 4). I am a native English-speaking teacher (NEST) and taught with twelve Japanese national non-native English-speaking teachers (NNEST) in two Niigata-based junior high schools throughout the 2017 to 2018 academic year. In one of the schools I spoke only English (whilst teaching and outside of class), and in the other school I spoke the students' L1s (Japanese and Spanish), and English (students' L2). My classroom experiences are discussed through reflective practice. Data from questionnaires and interviews indicate NNESTs' perceptions of the study and opinions of teaching English through English (TETE). I finally discuss challenges that the TETE experience presented to my teaching and suggest ways to overcome them.
\end{abstract}

本論は、文部科学省 (MEXT) の「生徒の理解の程度に応じて、中学校 では授業は英語で行うことを基本とする」(MEXT, 2014: 4) という近年の 方針に対する教員側からの受け止方について調査したものである。英 語母語話者の教員 (NEST) である筆者は、2017-2018年度に非英語母語 話者の日本人英語教員 (NNEST) 12名とともに新潟県の中学校2校にお いて英語を指導した。実験群の学校ではNESTは指導中に英語のみを話 し、統制群の学校では生徒の母語である日本語及びスペイン語 (L1) と英 語（L2）で話した。教室におけるNESTの体験について振り返りを基に議 論された。本研究に対するNNESTの受け止め方や、英語を英語で指導し た授業 (TETE) に関する意見はアンケートおよびインタビューによって収 集された。本論は、英語を英語で教えることの課題や、それを克服する方 法について論じている。

\section{English Instruction: From High School to Junior High School}

In the 2011 curriculum guidelines for public schools, the Course of Study $(\mathrm{CoS})$, the Japanese Ministry of Education (MEXT) advised teachers to teach English through English in senior high schools, in principle (MEXT, 2011). Since implementation, a growing body of research has investigated the language(s) that Japanese national non-native English-speaking teachers (NNESTs) at this level of schooling use to instruct. Research has focused on NNESTs that are either not teaching English through English (TETE) or using it seldomly, and identified reasons for this (Suzuki \& Roger, 2014; Nagamine, 2014; Machida, 2019). Such research has been proactive in suggesting how professional development may help achieve the MEXT goal in view of individual abilities and institutional constraints. To date, native English-speaking teachers (NESTs) have not been included in TETE research (at any level of schooling) and little is known about the language(s) they use to teach.

The 2014 CoS brought the TETE policy to teachers in junior high schools (JHSs). To date only limited research has been done on NNESTs' views towards the TETE policy, and none (to my knowledge) on NESTs'. In order to address this current lack of research into TETE in JHSs this research reports on my subjective teaching experiences of TETE at one JHS, and discusses the views of 12 NNESTS who, at the time of the study, had not started TETE. The three goals of this study are to explore JHS NNEST perspectives toward the TETE policy; discuss issues I had, as a NEST, when TETE in a public JHS, and ways I overcame them; and share information (interpersonal and institutional) influencing teachers' professional performance inside Japanese public schools, from a teacher perspective.

\section{Leading up to TETE in Japanese Public JHS}

One of the major trends in language education across the globe has been English-medium courses, particularly in higher education. In Japan, the number of universities offering English as a medium of instruction increased 50\% between 2005 and 2013 (Brown, 2016), and in high schools (HS) English teachers have been expected to provide instruction in English since 2011. This paper explores the 2014 $\mathrm{CoS}$ that states JHS "classes will be conducted in English in principle," a reform incrementally implemented from 2014 with "full-scale implementation by 2020 " (MEXT, 2015, p.4).

Research at higher levels of education has found teachers unsuccessfully implementing the TETE policy and explored reasons why. As this is a recent 
policy for JHSs, current research is mostly from senior high schools and universities. From such previous research, numerous issues resulting from English instruction in English have emerged, and it is expected that the same issues will be seen in JHSs, which are the focus of this paper. The primary themes concerning why the TETE policy has not been successful are found at the macro (governmental), meso (institutional), and micro (classroom/ teacher) levels (Beacco et al., 2010).

A key macro force guiding diverse NNEST teaching practices relates to the government-backed promotion of decentralisation (Jacobs, 2003). Increased regional autonomy is seen in the $2008 \mathrm{CoS}$ as "local governments are responsible for implementing education that suits the needs and circumstances of respective regions" (para. 20). As a result, municipal and prefectural BoEs (boards of education) interpret policy documents and direct NNESTs to teach according to their own educational philosophies. One common outcome of this practice is that the links between policy discourse and teaching practice are generally described as problematic (McConnell, 2000; Ng \& Boucher-Yip, 2016; Miyashita, 2017).

At the meso and micro levels, four central themes have emerged which aim to provide reasons for Japanese national NNESTs' continued use of Japanese to instruct:

1. Teachers' lack of time to prepare for classes. This relates to the wider school culture and their workloads outside of teaching (Hiratate, 2003). Time is taken away from preparing for classes and teaching by administrative and club duties (O'Donnell, 2005; Yorimitsu, Houghton, \& Taylor, 2014). The additional workload these extra duties create restricts daily pedagogy and professional development.

2. Related to workload, not all NNESTs have time to read the CoS or they misunderstand it (Koby, 2015). Teachers misinterpreting the CoS stem from the interpretable nature of its contents. In one study, JHS NNESTs described the ambiguities of what the TETE policy means and how to implement it (Takegami, 2016).

3. A large portion of the research on NNESTs in Japanese public schools focuses on their use of the grammar-translation approach, an approach MEXT has not supported since the 1980s (Tahira, 2012). Grammar-translation encompasses explanations of vocabulary and grammar in the L1 and fails to teach language for communication (Cook, 2001). Key reasons often given for the continued use of grammar translation is that NNESTs may continue to teach how they were taught (Nagamine, 2014), and training standards. In years previous, few professional training opportunities for TETE were offered in both junior high and high schools (Igawa, 2013, Machida, 2019).

4. Suzuki and Roger (2014) critically studied the relationship between NNEST English ability and teaching competency. They found a significant correlation in how this relationship affected their ability to TETE. A key conclusion of this study was that Foreign Language Anxiety (FLA) inhibits teacher cognition and loss of face (particularly in the teacher-centred classroom). The influence of affective barriers to affective teaching was also noted by Takegami (2016) who found that HS and JHS NNESTs held "insecure feelings on how to implement the (TETE) reform" (p. 25). NNESTS in Takegami's study felt insecure about implementing TETE because of personal views of their own English language ability. The consensus among NNESTs in her study was that were there was a lack of pedagogical knowledge regarding TETE during their pre-service training, and that using their L1 was the only effective way to teach grammar. JHS teachers in Machida's (2019) study stated clearly that the English policy "will not succeed" (p.19) without improved proficiency and speaking skills (all teachers in the study noted the need for training, too).

To combat some of these challenges, MEXT commissioned teacher training for JHS NNESTs. The Leader of English Education Project (LEEP) was a one-day training session run by the British Council (British Council, 2015) twice in 2018. Two JHS NNESTs from each prefecture (higher numbers from Hokkaido, Osaka, and Tokyo) travelled to Tokyo and Tsukuba to receive training, with an aim for them to train NNESTs in their respective prefectures cascade style (teachers teaching other teachers, who go on to teach other teachers) over the coming years.

Alongside Japanese national NNESTs, foreign nationals are employed to work in an assistant team-teaching capacity. The policy practice gap is seen in this working relationship as, since the current ALT system started in 1987, it has been widely reported that NESTs are not assisting, but lead teaching (AJET, 2014; Kano, Sonada, Schultz, Usukura, Suga, Kiyotaka, et al., 2015; McConnell, 2000). The ability for NESTs to effectively TETE can also be called into question as it is neglected in research, and no official training for it currently exists. 


\section{Methodology \\ Research Questions}

To address the issues of NNEST workloads, use of non-communicative teaching methodologies, confidence using English, and the lack of research on NEST teaching practices, three research questions were investigated:

1. How prepared are JHS teachers for TETE?

2. What are the main factors that either impede or support TETE in JHSs?

3. For the $2014 \mathrm{CoS}$ to be realised, what steps need to be taken?

\section{Research Setting and Participants}

I worked in two JHSs during the 2017-2018 academic year; I taught using only English in the one of the schools, which I will refer to as the TETE school, and I code-switched between English (target language) and both Japanese and Spanish (student L1s) in the other school, which I have called the code-switching school. The local BoE had not implemented the TETE policy in the schools in their district at the time of the study but granted permission for me to trial it for research purposes.

Table 1 below summarizes information for each school. NESTs work irregularly at schools and can visit up to 20 different schools each month. As I was working at two schools (two days a week in the TETE school and three in the code-switching school), I taught in each classroom twice every six weeks on average.

Table 1. Details of the TETE and code-switching schools

\begin{tabular}{lcc}
\hline & $\begin{array}{c}\text { TETE } \\
\text { School }\end{array}$ & $\begin{array}{c}\text { Code-switching } \\
\text { school }\end{array}$ \\
\hline \# of classrooms & 17 & 27 \\
\# of NNESTs & 5 & 7 \\
\# of times a month & 18 & 18 \\
$\begin{array}{l}\text { I taught in each } \\
\text { classroom }\end{array}$ & & \\
\# of students in & 489 & 787 \\
each school & & \\
\hline
\end{tabular}

\section{Procedure and Data Collection}

In the academic year prior to the study (2015-2016), the local board of education approved my request to speak only English in one school and to code-switch in the other for research purposes. Following this, I worked with two NNESTs in a JHS (separate to the two in the study) to develop a questionnaire distributed at the end of the study. The NNESTs used their years of experience (each over 20 years) to develop questions related to working with a NEST and MEXT educational policies. We trialled it with six NNEST colleagues who had no connection with the NNESTs in the study.

At the start of the study (April 2017) I held a meeting with the 12 NNESTs at each school and the two school principals to explain the study. All NNESTs were individually asked to participate as assistants in the classroom while I taught, and only to support if asked to (see Appendix A for the NNEST profiles). They were briefed on the purposes of the study (a trial for the MEXT TETE policy) and signed a consent form clarifying that their anonymity was assured. All 12 NNESTs completed a post-study questionnaire (Appendix B) and interview. A professional conversation (Kvale, 1996) interview style was used so interviewees could steer the conversation as they liked while following approximate interview questions. The questions I used to guide these interviews are in Appendix $\mathrm{C}$ and the full transcripts can be found at ALTTO.net/resources. I collected experiential data through reflective practice and a teacher journal.

\section{Findings and Discussion}

\section{NNESTs Perceptions on their Preparedness to Implement the TETE Policy}

Research question one asks how prepared JHS teachers are for the TETE policy. During the poststudy interviews, only two of the twelve NNESTs in the study expressed that they felt ready to teach speaking in English only. One NNEST stated, "I often do only English classes" and the other that NNESTs mostly use English in the classroom. However, ten expressed less confidence in their abilities, saying that they did not use much English in the classroom and showed anxiety toward TETE, saying such things as "I don't want to teach (in) English," "I will be nervous, I don't have confidence," "I can't speak English," and "I'm glad l'm retiring." The findings from this study at the JHS level, connecting a sense of anxiety toward the TETE policy and language ability, almost replicate those from research at the HS level (Suzuki \& Roger, 2018).

Three NNESTs at the start of the study stated they were not aware of the TETE policy (Table 2), which could suggest a lack of preparation on their part (not reading the CoS), the local BoE (for not explaining the reforms clearly), or MEXT (for not disseminating information effectively). Teachers 
cannot be prepared to achieve CoS guidelines if they do not know what they are.

Table 2. NNEST post-study responses: Do you read the English section of the Course of Study guidelines? (the numbers in the tables signify individual teacher responses)

\begin{tabular}{|l|l|l|l|l|l|l|}
\hline Yes, all of it & 0 & 2 & 4 & 3 & 3 & $\begin{array}{c}\text { No, none } \\
\text { of it }\end{array}$ \\
\hline
\end{tabular}

Five of the twelve NNESTs were undecided (choosing the $50 \%$ option) about how realistic it would be for JHS teachers to speak only in English whilst teaching. The findings here reflect confidence levels in teaching and language ability, but also put a question mark over how prepared the majority of NNESTs in this study are to teach in English.

Seven of the twelve NNESTs believed that (all) NNESTs need more training to implement TETE (Table 3). This feeling of unpreparedness is amplified by the lack of professional development opportunities. None of the NNESTs in the study had heard of the LEEP training (which had been announced over two years prior to the study), or any other specific training to prepare teachers for the TETE policy.

Table 3. NNEST post-study responses: Do you think NNESTs need more training to meet the 2020 Course of Studies goals?

\begin{tabular}{|l|l|l|l|l|l|l|}
\hline Yes & 7 & 3 & 2 & 0 & 0 & No \\
\hline
\end{tabular}

There was a shared belief that NESTs need training to be able to provide English instruction (Table 4). The NNESTS in this study reported not knowing about the training NESTs receive. All showed some level of surprise at how little NEST teacher training there is.

Table 4. NNEST post-study responses: Do you think NESTs need more training to meet the 2020 Course of Studies goals?

\begin{tabular}{|l|l|l|l|l|l|l|}
\hline Yes & 4 & 5 & 3 & 0 & 0 & No \\
\hline
\end{tabular}

\section{Issues Experienced in Implementing TETE}

On considering reflection question two, exploring factors that impede or support TETE, I examined teaching areas that were challenging for me. I also considered meso level factors that school decision makers should keep in mind for the successful implementation of the policy. Whilst teaching, five issues came up that highlighted how the training my employer provides (no pre-service and 2-hour monthly in-service meetings) was ineffective in developing my skills to successfully implement TETE. Teaching grammar, giving instructions, comprehension checking, class management, and eliciting vocabulary all proved challenging, particularly in the early months of the study. As time went on, through critical reflection and conversations with NNESTs, each of these areas improved.

Explaining a grammar point, instructing students about how to complete worksheets, and comprehension checking took up to 20 minutes of class time in the TETE school. These long explanations frustrated students and me, resulting in boredom and diminished student learning outcomes. In the code-switching school, none of the five issues arose as I could provide a quick explanation and comprehension check in the students' L1s. Issues relating to instruction frequently came up in conversations throughout the year as NNESTs acknowledged how long it took and empathised with my frustrations. Through these conversations, we discussed ways to TETE. For example, by developing adaptable worksheets and writing clear example sentences on the board to teach grammar.

In the TETE school, NNEST views of how prepared I was to TETE were mixed. Concerning the long instructions, two NNESTs wrote conflicting comments in the questionnaire, "you should teach in detail how to explain about each task," and "you taught our students again and again until they understood." These opposing comments were perhaps the result of differing interpretations of my lessons and may reflect the teachers' individual teaching philosophies. Despite these opposing views, NNESTs in the TETE school actually indicated that they preferred not to work in a team-teaching capacity (Table 5) and that the NEST should teach alone, unlike NNESTs in the code-switching school (Table 6).

Table 5. NNEST post-study responses (TETE school): Was it preferable for the ALT to teach solo (not team teach)?

\begin{tabular}{|c|c|c|c|c|c|c|}
\hline Preferable & 3 & 2 & 0 & 0 & 0 & $\begin{array}{c}\text { Not } \\
\text { preferable }\end{array}$ \\
\hline
\end{tabular}


Table 6. NNEST post-study responses (Code-switching school): Was it preferable for the ALT to teach solo (not team teach)?

\begin{tabular}{|l|l|l|l|l|l|l|}
\hline Preferable & 2 & 0 & 2 & 3 & 0 & $\begin{array}{c}\text { Not } \\
\text { preferable }\end{array}$ \\
\hline
\end{tabular}

The factor impeding TETE here could lay at the macro governmental level that (officially) requires non-Japanese nationals to teach in assistant capacities. NNESTs in the code-switching school could have been using this instilled practice to guide their responses. As NNESTs in the TETE school were able to witness a NEST TETE they had the opportunity to see in practice how pedagogically effective this classroom dynamic could be. This line of enquiry also comes from previous research related to NNESTs' language anxiety; as most NESTs are English L1 speakers, this is not an issue. Some support for this macro level impediment to more successful implementation of the TETE policy comes from NNESTs views of how professionally rewarding it was to work in a supportive position, with all 12 answering it was rewarding to at least some extent (Table 7).

Table 7. NNEST post-study responses: Describe your perceptions of supporting the NEST. Was it: professionally rewarding (I learnt new teaching techniques, new ways to teach communicatively...)?

\begin{tabular}{|l|l|l|l|l|l|l|}
\hline Very much & 6 & 6 & 0 & 0 & 0 & $\begin{array}{c}\text { Not so } \\
\text { much }\end{array}$ \\
\hline
\end{tabular}

This research found similar factors impeding TETE in the JHS context as has been found in HS contexts (Nagamine, 2014; Suzuki \& Roger, 2014). Conversations throughout the year suggested that the NNESTs had limited awareness of MEXT goals, with the primary reason for not reading the CoS being time. The average amount of time at schools that NNESTs in this study spent preparing for classes was $40 \%$ of working time, but as two teachers were retiring and assigned fewer responsibilities, this percent may be high (one teacher in O'Donnell's 2008 study estimated spending 30\% of work time on teaching responsibilities). Time, and lack of it, frequently came up when discussing professional development to prepare for TETE. Ten NNESTs could not envision how they could commit to developing their TETE abilities.

A contextual factor inhibiting English instruction, as described by an NNEST, was when teachers and students share the same language. The study inspired one NNEST in the TETE school to try TETE for the first 10 minutes of some classes when I was not present. He explained that students answered his questions in Japanese and concluded from this experience that "it is not a good situation for the NNEST as they know I can help them." He believed that NESTs' teaching with no assistance from an NNEST was "a good way to teach." Another NNEST at the same school had an opposing view. She stated that she wanted to "give students advice" in Japanese while I was teaching, adding that she would have liked me to accept her help in Japanese. Ten of the NNESTs intermittently expressed throughout the study that they will rely on grammar translation and Japanese to teach even after 2020. It is unclear if this teaching ideology stems from their English competency, teaching ability, or prior learning experience.

I occasionally used student L1s (Japanese and Spanish) in the TETE school when I could not make the meaning of a word or instruction understood. Sometimes I asked NNESTs and multilingual/advanced students to translate Japanese words. Over time, I developed ways to simplify grammar and activity explanations to rely on this less. The strategy of relying upon NNESTs to translate single words entailed certain risks, such as NNESTs not knowing the word, not focusing on the class enough to understand the context (e.g., they were marking papers at the back of the class), and not being present in the classroom. Meso and micro level factors impeding English instruction here relate to my teaching skills, NNEST English competency, and workloads, as some NNESTs used my class time to catch up on other duties.

\section{Implications and Suggestions for Improvements}

Based on my experience in this study, one way to move closer to the TETE policy (research question three) is for bottom-up training and increased communication between teachers. All NNESTs believed that teachers (NESTs and NNESTs) need more training and that they do not currently have access to sufficient training: two NNESTs in the study had paid for training outside of school work hours at their own expense. In line with policy documents and the Japanese public school context, Miyashita (2017) calls for EFL teachers to form a bottom-up community of teachers to peer-develop pedagogical skill by critically analysing policy documents and implementing practices that fit specific settings. Utilising independent training sources, such as ALT Training Online (2020), a voluntary professional development resource, can be used to support bottom-up training (Hougham et al., 2017). 
Unfortunately, this study cannot offer any resolutions to the institutional time limitations or NNESTs' English abilities. However, one humanistic finding supporting TETE relates to interpersonal relationships. NNESTs were asked of their perceptions of the study and about their professional relationships with me in the first seven questions in the post-study questionnaire. Some of the teachers indicated that working in a supporting role was a form of professional development, with one teacher writing "You helped me a lot. You have many ideas to teach, use, and make them (the students) speak English.” This provides support for TETE through team-learning. First popularised by Tajino and Tajino (2000), team-learning emphasizes NNESTs and NESTs making a focused effort to learn from one another. As the NEST in this study, I found that team-learning was primarily developed through empathy. As I battled through the year in the TETE school, I had daily conversations with the NNESTs on preparing for lessons, issues relating to TETE and discussions on how to teach grammar and vocabulary. In the code-switching school, the NNEST/ NEST dynamic was kept at a strictly informative level: memos were left on my desk with comments on what grammar point they would like me to teach that day, with little interaction concerning pedagogical matters. Feelings of supporting the educational growth in students and relationships with school staff (in the TETE school) were compared with feelings of isolation and of being a person of nominal institutional value at the code-switching school. From this study, practical steps to come closer to meeting the MEXT TETE goals include: NESTs being assertive when lesson planning, empathizing with NNEST workloads, talking to NNESTs about how they aim to reach shared teaching goals, and making efforts to understand each other's previous training and language abilities.

\section{Limitations}

The primary limitation of this study was that I was the researcher commenting on my perceptions of my own teaching practices. Thus, researcher experiences and NNEST responses are viewed through this subjective lens. In addition, although the questionnaire was translated into Japanese, the poststudy interviews were conducted in the NNESTs L2 (English), so they may not have been able to express their thoughts as clearly as they could have in Japanese (their L1). Also, as this research took place before TETE was introduced at the schools, views of the NNESTs were, mostly, not from experiential practice, but rather envisioned. Future studies should examine in-practice factors impacting effective TETE with data collection in teacher's L1s.

\section{Conclusions}

My experience of English instruction in this study was challenging and rewarding; it was a demanding learning curve that my previous training and experience in Japan did not prepare me for. Previous training and experience, continual self-reflection, and discussions with NNESTs helped to develop my TETE techniques. The views of ten NNESTs in the study related to being unprepared because of limited TETE training and English ability. Although two NNESTs expressed readiness for TETE, ten said they were not ready, indicating that the policy may not be widely adopted over the coming years. Three ways to promote TETE implementation and improve educational standards are for all teachers to gradually increase the amount of comprehensible English in their instruction, for all teachers to continually make time to discuss pedagogical matters, and to regularly reflect on classes.

\section{References}

AJET. (2014, June 16). Assistant Language Teachers as Solo Educators. https://ajet.net/downloads/reports/2014/ ALTs_as_Solo_Educators_ENG.pdf

ALT Training Online. (2020, June 25). Professional development-ALT Training Online (ALTTO). ALTTO. https://altto.net/

British Council. (2015). Junior High School Teacher Training 2018: LEEP Trainer Notes. Tokyo.

Beacco, JC., Byram, M., Cavalli, M., Coste, D., Cuenat, M.E., Goullier, F., \& Panthier, J. (2010). Guide for the development and implementation of curricula for plurilingual and intercultural education. Directorate of Education and Languages, DGIV. Council of Europe, Strasbourg. https://www.dphu.org/ uploadsattachements/books/books_4820_0.pdf

Brown, H. (2016). English-medium instruction in Japan: Discussing implications for language teaching. In P. Clements, A. Krause, \& H. Brown (Eds.), Focus on the learner (pp. 419-425). Tokyo: JALT. https://jalt-publications.org/ node/4/articles/5418-english-medium-instruction-japandiscussing-implications-language-teaching

Cook, V. (2001). Using the first language in the classroom. Canadian Modern Language Review/Revue Canadienne Des Langues Vivantes, 57, 402-423. https://:doi. org/10.3138/cmlr.57.3.402

Hiratate, H. (2003). Teacher suicides and the future of Japanese education. The Asia Pacific Journal, 1(9), 1-9. https://apjjf.org/-Hiratate-Hideaki/1940/article.html

Hougham, D. G. C., Walter, B. R., \& Sponseller, A. C. (2017). Practicalities implications and steps to succeed for teacher education and support. In P. Clements, A. Krause, \& H. Brown (Eds.), Transformation in Language Education (pp. 135-145). Tokyo: JALT. https://jalt-publications.org/sites/ default/files/pdf-article/jalt2016-pcp-018.pdf

Igawa, K. (2013). Language proficiency development needs of NNS English teachers in Japan. Shitennoji University Bulletin, 56, 1-25. http://www.shitennoji.ac.jp/ibu/docs/ toshokan/kiyou/56/kiyo56-13.pdf 
Jacobs, A. J. (2003). Devolving authority and expanding autonomy in Japanese prefectures and municipalities. Governance, 16, 601-623. https://doi.org/10.1111/14680491.00230

Kano, A., Sonada, A., Schultz, D., Usukura, A., Suga, K., \& Yuriko, Y. (2015). Barriers to effective team teaching with ALTs. In P. Clements, A. Krause, \& H. Brown (Eds.), Focus on the learner (pp. 74-82). Tokyo: JALT.

Koby, C. (2015). Communicative competence in high school? Really?. In P. Clements, A. Krause, \& H. Brown, JALT2014 Conference Proceedings (pp. 126-132). Tokyo: JALT. https://jalt-publications.org/files/pdf-article/ jalt2014proc_012.pdf

Kvale, S. (1996). Interviews: An Introduction to Qualitative Research Interviewing. Thousand Oaks, CA: Sage.

Machida, T. (2019). How do Japanese junior high school English teachers react to the teaching English in English policy? JALT Journal, 41(1), 5-26. https://doi. org/10.37546/JALTJJ41.1-1

McConnell, D. (2000). Importing Diversity: Inside Japan's JET Program. CA: University of California Press.

MEXT. (2011). The revisions of the courses of study for elementary and secondary schools. https://www.mext. go.jp/en/policy/education/elsec/title02/detail02/_ icsFiles/afieldfile/2011/03/28/1303755_001.pdf

MEXT. (2014). Report on the Future Improvement and Enhancement of English Education (Outline): Five Recommendations on the English Education Reform Plan Responding to the Rapid Globalization. https://www. mext.go.jp/en/news/topics.detail/1372625.htm

MEXT. (2015). Plans on the Promotion of Improvement of Students' English Abilities. https://www.mext. go.jp/en/news/topics/detail/_icsFiles/afieldfi le/2016/10/19/1378469_001.pdf

Miyashita, H. (2017). Critical analysis of English education policies in Japan focusing on two discourses: Developing human resources and nurturing Japanese identity. World Journal of English Language, 2, 10-21. https://doi.org/10.5430/wjel.v7n2p10

Nagamine, T. (2014). Preservice and inservice English as a foreign language teachers' perceptions of the new language education policy regarding the teaching of classes in English at Japanese senior high schools. In K. Shimizu \& W.S. Bradley (Eds.), Multiculturalism and Conflict Reconciliation in the Asia-Pacific (pp. 99-117). London: Palgrave Macmillan. https://doi. org/10.1007/978-1-137-40360-5_6
Ng, P. C. L., \& Boucher-Yip, E. F. (2016). Teacher Agency and Policy Response in English Language Teaching. New York, NY: Routledge. https://doi. org/10.4324/9781315646701

O’Donnell, K. (2005). Japanese secondary English teachers: Negotiation of educational roles in the face of curricular reform. Language, Culture and Curriculum, 18(3), 300-315. https://doi. org/10.1080/07908310508668749

Suzuki, H., \& Roger, P. (2014). Foreign language anxiety in teachers. JALT Journal, 36(2), 175-199. https://doi. org/10.37546/JALTJJ36.2-2

Tahira, M. (2012). Behind MEXT's new Course of Study Guidelines. The Language Teacher, 36(3), 3-8. https:// doi.org/10.37546/JALTTLT36.3-1

Tajino, A., \& Tajino Y. (2000). Native and non-native: What can they offer? Lessons from team-teaching in Japan. ELT Journal, 54(1), 3-11. https://doi.org/10.1093/ elt/54.1.3

Takegami, F. (2016). An exploratory study on the impact of the new teaching English through English (TETE) curriculum policy in Japan: A case study of three teachers. International Journal of Social and Cultural Studies, 9, 15-45. https://kumadai. repo.nii.ac.jp/?action=pages_view_main\&active action=repository_view_main_item_detail\&item_ id=29461\&item_no=1\&page_id=13\&block_id=21

Yorimitsu, A., Houghton, S., \& Taylor, M. (2014). Operating at the margins while seeking a space in the heart: the daily teaching reality of Japanese high school teachers experiencing workplace stress/anxiety. Asia Pacific Education Review, 15(3), 443-457. https://doi. org/10.1007/s12564-014-9330-0

Nathaniel Reed has been teaching English in Japan since 2009. He started working as an ALT in Niigata from 2014 and holds an MA in linguistics from the University of Birmingham, in addition to TEFL and CELTA qualifications. A proud father of two, he juggles parenting with

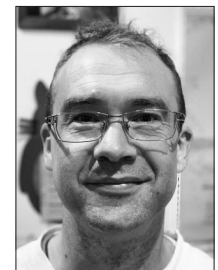
developing an open access online training system for ALTs (ALTTO.net), and classroom research. His research interests include intercultural communication, teacher training and EFL pedagogy.

\section{Appendix A}

\section{NNEST Profiles (pseudonyms used for people and schools)}

\begin{tabular}{|l|c|c|c|c|c|}
\hline \multicolumn{7}{|c|}{ Red Lake - TETE school } \\
\hline Name & Teddy (M) & Wolfgang (M) & Chantal (F) & Olympia (F) & Yassir (M) \\
\hline Years teaching & 30 & 27 & 24 & 30 & 30 \\
\hline $\begin{array}{l}\text { Time abroad } \\
\text { (study or travel) }\end{array}$ & $\begin{array}{c}2 \text { months } \\
\text { studying English } \\
\text { in U.S. }\end{array}$ & $\begin{array}{c}1 \text { month U.S. } \\
\text { teacher training }\end{array}$ & None & None & None \\
\hline $\begin{array}{l}\text { Undergraduate } \\
\text { degree }\end{array}$ & English language & Pedagogy & Literature & Linguistics & English language \\
\hline
\end{tabular}




\begin{tabular}{|l|c|c|c|c|c|c|c|}
\hline \multicolumn{7}{|c|}{ Newark - Code-Switching School } \\
\hline Name & Icy (M) & Ora (F) & Kailey (F) & Harmony (F) & Nickolas (M) & Hamza (M) & Kathleen (F) \\
\hline Years teaching & 17 & 26 & 7 & 21 & 21 & 30 & 4 \\
\hline $\begin{array}{l}\text { Time abroad } \\
\text { (study or travel) }\end{array}$ & $\begin{array}{c}\text { 3 weeks in } \\
\text { England (in } \\
1998)\end{array}$ & None & None & $\begin{array}{c}2 \text { weeks in } \\
\text { UK }\end{array}$ & $\begin{array}{c}\text { 6 months at } \\
\text { U.S. univer- } \\
\text { sity }\end{array}$ & None & $\begin{array}{c}2 \text { weeks in } \\
\text { Australia } \\
\text { and England } \\
\text { to study }\end{array}$ \\
\hline $\begin{array}{l}\text { Undergraduate } \\
\text { degree }\end{array}$ & Literature & Literature & $\begin{array}{c}\text { American } \\
\text { literature }\end{array}$ & Education & Literature & Education & $\begin{array}{c}\text { English } \\
\text { education }\end{array}$ \\
\hline
\end{tabular}

\section{Appendix B}

\section{NNEST Post-study questionnaire}

1. Describe your perceptions of this year. Was it easy to work together/cooperate professionally in the classroom?

2. (TETE) Describe your perceptions of this year. Was it preferable for the ALT to teach solo (not team teach)?

3. (TETE) Describe your perceptions of this year. Was it preferable for the ALT to teach in English only?

3. (Code-switching) Describe your perceptions of this year. Was it preferable for the ALT to teach in English and Japanese?

4. Are other factors, not language, important for working together with an ALT (e.g., personality)?

5. (Code-switching) Describe your perceptions of this year. Did the ALT speak too much Japanese whilst teaching?

5. (TETE) 6 (Code-switching) Describe your perceptions of supporting the ALT. Was it professionally reward-

ing (e.g., I learnt new teaching techniques. I learnt new ways to teach communicatively...)?

6. (TETE) 7. (Code-switching) Describe your perceptions of supporting the ALT. Was it difficult?

7. (TETE) 8. (Code-switching) Describe from your professional opinion of how English classes were from student perspectives. Did students speak more English in classes taught solo by a JTE?

8. (TETE) 9. (Code-switching) Describe your professional opinion of how English classes were from students' perspectives. Did students speak more English in classes taught solo by an ALT?

9. (TETE) 10. (Code-switching) Describe from your professional opinion of how English classes were from student perspectives. Is it beneficial for students' language ability to be taught only in English?

10. (TETE) 11. (Code-switching) Describe from your professional opinion of how English classes were from student perspectives. Is it beneficial for students' language ability to be solo taught by a non-Japanese teacher?

11. (TETE) 12. (Code-switching) Describe from your professional opinion of how English classes were from students' perspectives. Students are more motivated to study English when: A) ALTs teach by themselves. B) JTEs teach by themselves. C) ALTs and JTEs teach together. (Circle one).
12. (TETE) 13. (Code-switching) Describe from your professional opinion of how English classes were from students' perspectives. Students are more motivated to speak English when: A) ALTs teach by themselves. B) JTEs tech by themselves. C) ALTs and JTEs teach together. (Circle one).

13. (TETE) 14. (Code-switching) This question relates to your views of MEXT English education policies: Do you read the English section of the Course of Studies?

14. (TETE) 15. (Code-switching) This question relates to your views of MEXT English education policies: How realistic do you think the 2020 Course of Studies goal of teachers only speaking English in junior high school classes is?

15. (TETE) 16. (Code-switching) This question relates to your views of MEXT English education policies: Do you think JTEs need more training to meet the 2020 Course of Study goals?

16. (TETE) 17. (Code-switching) This question relates to your views of MEXT English education policies: Do you think ALTs need more training to meet the 2020 Course of Study goals?

17. (TETE) 18. (Code-switching) This question relates to your views of MEXT English education policies: Should MEXT consult teachers more before writing the Course of Studies?

18. (TETE) 19. (Code-switching) How much do you agree with these sentences (as a percentage)? 'JTEs prepare students to pass tests, not to communicate. ALTs teach students to communicate, not to pass tests.'

19. (TETE) 20. (Code-switching) How much do you agree with this sentence from previous JTE research? 'ALTs leave just as they are getting good.'

20. (TETE) 21. (Code-switching) How much of your work time is dedicated to preparing for English classes (as a percentage)?

20. (TETE) 22. (Code-switching) Provide any comments about this study.

\section{Appendix C}

\section{Post study interview questions}

- What do you think about the English only policy?

- Will you teach in English?

- What are the challenges going to be when TETE?

- What can you do to use more English whilst teaching?

- Would teacher training help? 